\title{
Status and Countermeasures of Ideological and Political Education of College Students under Internet Environment
}

\author{
LI Xia ${ }^{1, a}$ \\ ${ }^{1}$ Department of Communication engineering, Chongqing College of Electronic Engineering, \\ Chongqing ,401331 \\ a251797675@qq.com
}

Keywords: Internet, Ideological and Political Education, College Students

\begin{abstract}
With the popularity of the Internet, China gradually into the Internet era. College students as the ideological advanced group, become the main group of Internet users. The Internet also won the general recognition of college students' groups with its openness, sharing and interactive advantages, and infiltrated all aspects of life and study of college students. It greatly changed the way of life and way of thinking of college students, but also brought new opportunities and opportunities for college education. Colleges and universities must actively explore new ways of education, through the active integration of network advantages and ideological and political education, the establishment of ideological and political education professional website, with the Internet can improve the ideological and political education methods and content, adhere to appropriate countermeasures to deal with the network environment on ideological and political education challenges.
\end{abstract}

\section{Introduction of Ideological and Political Education}

With the development of the Internet, a network of human society has had a profound impact, not only in the production of economic, political and social ties and other aspects of life, but also for the development of cultural heritage and also play a huge impact. Popularity of the Internet caused a strong impact on the political culture, but will not quickly eliminate the political culture of the Internet age, the Internet age but first cause political and cultural change, it points to the reconstruction connotation, expand the extension of the scope of the Transformation form as well as in nature, impact and showed a greater difference in the Internet age political culture.

From the perspective of political culture to analyze the network of political culture and political culture is a combination of network technology, it is under the influence of networking tools, a new political subculture political culture by means of the development of network characteristics of the formation of that political culture network development. Network trend is becoming a new form of society in the new foundation. Political culture are not static, it is always in a constant process of change, a change in political culture have a certain historical period of political, economic, cultural and social spheres of influence, leading to a political culture has undergone some changes ${ }^{[1]}$.

College students' ideological and political education is based on the full use of computer networks, multimedia technology and modern communication technology and other means, based on the cognitive characteristics of contemporary college students designed a new ideological and political education method. It is through the relevant network construction and network ideological and political education information production, dissemination and control, in order to achieve with the correct, rich and vivid network of information to influence the ideological ideas, political views, moral norms, so that they form in line with socialism Society needs ideological and political moral and information support. Compared with the traditional media, the Internet has become an important channel for contemporary college students to obtain information and interpersonal communication, and has had an important influence on college students' thought, study and life because of their fast spread, big information and strong interaction. 


\section{Status of Network Environment Ideological and Political Education}

The openness of the network, the network of large-capacity information, so that college students access to knowledge, information channels to broaden the ideological and political education to expand the space, but also to the ideological and political education of college students more diversified means. But the network is also filled with all kinds of information, focused on the different national outlook, values, morality, which students have had a lot of negative effects. Colleges and universities to strengthen and improve the ideological and political education of college students to try, and achieved great success, but there are still several questions ${ }^{[2]}$. Fig.1 shows status of network environment ideological and political education.

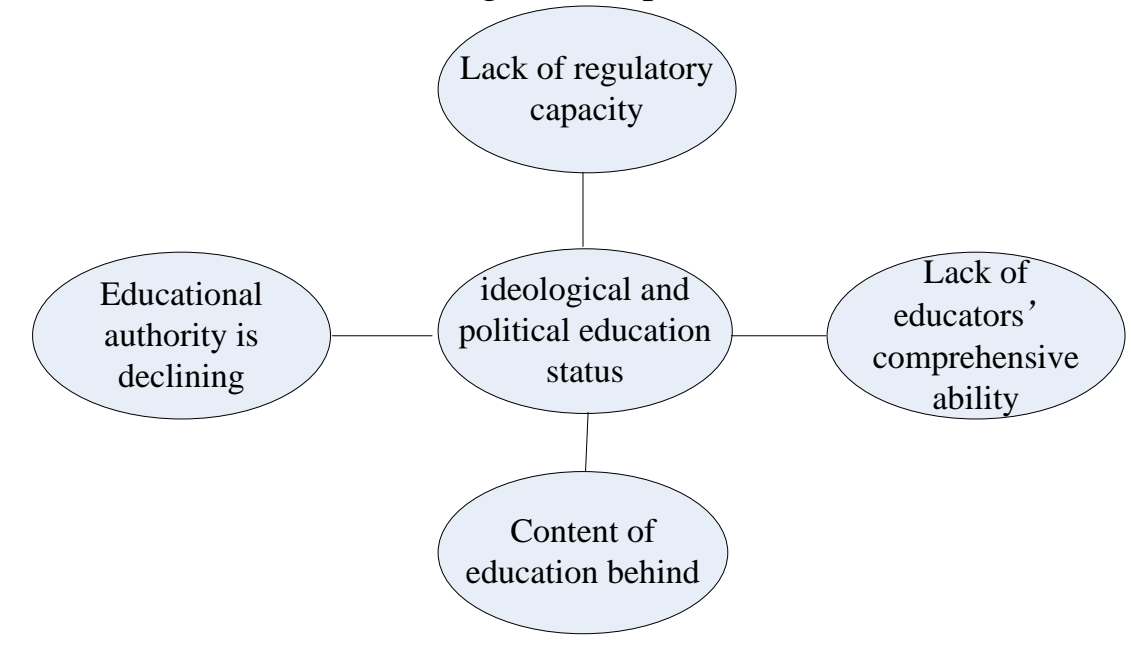

Fig. 1 The network environment Ideological and Political Education

In traditional ideological and political education, teachers are information transfer and decision makers. Educators establish the prestige in the guidance process, which is beneficial to the ideological and political education work carried out. The emergence of the network for students to provide a wealth of information resources, so that students enhance the choice of learning content of the initiative, greatly weaken the teacher in the traditional ideological and political education in the pilot, the authority of the greater challenge. Network culture is open, messy, messy, the ideology of college students have a strong impact. At present, some college students ideological and political education content and form in the network environment is relatively simple, still simply on the traditional ideological and political education content of the boring theoretical explanation, not the content and form of education and college students interested in solving practical problems ability and so on, leading college students to participate in ideological and political education of the enthusiasm and initiative, ideological and political education is less effective.

The quality of college students' ideological and political education workers directly affects the quality of their education. Under the network environment, some college students ideological and political education workers lag behind the pace of development of the information age, did not accept the system of computer training and learning, especially some older teachers, lack of understanding of the network culture, lack of proper network knowledge and technology, and take the initiative of ideological and political education and network technology combined with the concept of consciousness. It is difficult to fully grasp the network environment under the ideological dynamics of college students, can't meet the network environment ideological and political education on the quality of education needs. Most colleges and universities have campus stickers, forums, students have personal QQ, blog, etc., but most colleges and universities can be an effective supervision and control ${ }^{[3]}$.

\section{Advantages of Internet on College Students' Ideological and Political Education}

Under the Internet environment, the ideological and political education of college students is based on the network as the carrier, make full use of college students often use the advantages of 
computer technology and multimedia technology, ideological and political education network ideological and political education and college students cognitive approach is more combined ${ }^{[4]}$.

College students can break through the limited resources and opening hours of the library and the library, through the Internet to obtain the necessary knowledge and information and so on. At the same time, ideological and political workers in colleges and universities can use the Internet's rich teaching resources and rich and colorful forms of information to express the content of ideological and political education in the form of words, images and video, and spread the advanced and more rapidly to college students. Ideological and theoretical methods overcome the traditional way of education in the time and space constraints, thereby enhancing the ideological and political education, and political education platform. The flexibility and interactivity of the Internet is conducive to improving the way of ideological and political education of college students. The Internet can display teaching content in various forms and enrich the means of ideological and political education of college students.

In the Internet age, college students are less limited by time and space, can choose the information they want to obtain, and can take a different way to reply to information sources, in order to participate in timely feedback and re-creation of information. This two-way interactive information exchange and exchange makes the educated by passive acceptance into active participation, changing the traditional way of education. The equality of the Internet is conducive to enhancing the effectiveness of ideological and political education, in the Internet environment, each individual can speak their minds, express their own ideas and insights. The ideological and political education of the university is easy to enter the spiritual world of college students through the Internet, understand the real thoughts of the students, master the students' ideological dynamics, and make the ideological and political work be targeted and improve the relevance and effectiveness. With the Internet, educators and educators have a covert and equal, virtual environment and role not only shorten the distance between the two sides, but also closer to each other's psychological distance, eliminate interpersonal psychological barriers between the elimination of teachers and students of the gap.

\section{Countermeasures of Strengthening Ideological and Political Education}

The ideological and political education of college students in the content, form, methods and means, but in the development of the Internet under a lot of people have changed. Therefore, colleges and universities should focus on the actual, advancing with the times, make full use of the new carrier of the Internet, enrich the content of ideological and political education, innovation work, methods and ideas, and earnestly strengthen and improve the ideological and political education of students ${ }^{[5]}$. Fig.2 shows the countermeasures of ideological and political education.

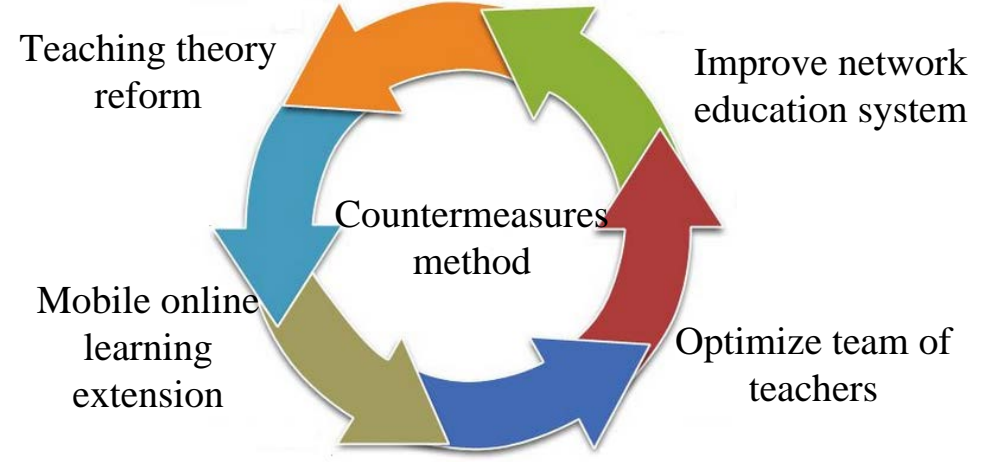

Fig. 2 Countermeasures of ideological and political education

In the Internet age, we should give full play to the main channel of ideological and political education of college students - the role of ideological and political theory course, through deepening the reform of teaching content, innovative teaching methods and teaching methods, and constantly enhance the ideological and political education targeted and effective, the role of efforts to explore ideological and political education for college students a new and effective way. Traditional 
classroom teaching has been unable to meet the growing needs of students learning, to be good at using micro-blog, We-Chat, QQ group and other Internet platform, the spread of college students vivid thoughts and information, and through interaction with college students, concerned about the idea of college students dynamic. In order to better guide online public opinion, universities should be a conscious, proactive training college students in thoughtful, knowledgeable higher political consciousness of opinion leaders.

In the Internet age, college students in the use of the Internet, information mining and access to the ability and beyond the scope of ideological and political education workers, which requires colleges and universities must establish a strong political quality, strong business ability, innovative and innovative spirit, Internet technology and the ability to flexibly use the mobile Internet to carry out ideological and political education work of ideological and political education workforce. Under the Internet environment, the ideological and political education of college students is a systematic project. Colleges and universities should make clear their ideas, unify their understanding, top-level design, long-term planning, establish leadership system of party and government leaders in colleges and universities, and focus on grasping the development of schools Network ideological and political education work system norms, from the staffing, system security, financial support, technical monitoring and other aspects to further strengthen the resource aggregation, integration and coordination.

\section{Conclusions}

With the rapid development of Internet technology, computers, mobile phones and digital technology as the representative of the Internet has been widely used, increasingly affecting and changing people's social life. People and students to accept the cultural and educational level is relatively high, is undoubtedly attracted by the Internet faster, into the faster, faster application of the crowd. The development of the Internet has brought new challenges to the ideological and political education of the students, and put forward some new requirements to strengthen the ideological and political education of the students. Ideological and political education in colleges and universities make full use of the advantages of the Internet, innovative students ideological and political education methods and means to clear objectives, scientific management. In the current Internet environment, fully understand and grasp the new problems of ideological and political education of students, further strengthen and improve the ideological and political education under the new situation, it is particularly important.

\section{References}

[1] Ullman, J. Structural equation modeling: Reviewing the basics and moving forward [J]. Journal of Personality Assessment, 87(1): 35-50. 2006.

[2] Hatemi, P. K., Funk, C. L., Medland, S. E., Maes, H. M Silberg J. L., Martin, N. G \&Eaves, L. J. Genetic and environmental transmission of political attitudes over a life time [J]. Politics Journal, 71(3), 1141- 1156, 2009.

[3] George, R. Political socialization in the everyday interactions of Los Angeles families [J]. Discourse \& Society, 24(1), 46-65. 2013.

[4] Xiang Haiyan. Influence of Network Environment on College Students' Ideological and Political Education [J]. Today's Chinese Forum, 2013, (19): 50-52.

[5] Shen Yao. Study on the ideological and political education of college students under the network environment [J]. Pixie 2014, (3): 108-10 109. 